\title{
ACCOUNTING OF REAL COSTS FOR THE PRODUCTION OF ORGANIC FOOD: WORLD EXPERIENCE AND PRACTICE OF UKRAINE
}

Yana Ishchenko Vinnytsia National Agrarian University, Ukraine E-mail: jana_2006@ukr.net

Olena Podolianchuk Vinnytsia National Agrarian University, Ukraine E-mail: podolianchuk_l@i.ua

Nataliya Struk Ivan Franko National University of Lviv, Ukraine E-mail: nataliya.struk@Inu.edu.ua

Valentyna Yasyshena Vinnytsia education and research institute of economy of West Ukrainian National University, Ukraine E-mail: valentyna.yasyshena@gmail.com

Svitlana Stender State Agrarian and Engineering University in Podilya, Ukraine E-mail: stender1976@gmail.com

Submission: 8/25/2021

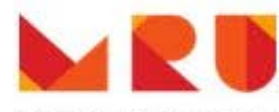

MYKOLAS ROMERIS UNIVERSITY

\section{ABSTRACT}

The purpose of the publication is to study the current state of the organization and methods of accounting for the costs of organic production from the point of view of environmental and economic accounting in Ukraine and recommendations for adapting accounting support for managing the costs of production of organic products to the requirements of the formation of integrated information of environmental and economic accounting. To determine the general trends in the development of accounting support for managing the costs of the production of organic products, the methods of induction and deduction were used. The economic and statistical method was used to analyse the state of production of organic products, and the observation method was used to study the state of accounting for the real costs of producing organic food. 
The state of development of organic production for the period from 2000 to 2019 in the world, Europe and Ukraine has been analysed. It has been determined that at the micro level, in the conditions of organic production, environmental and economic accounting is an information system that allows you to monitor compliance with the requirements of domestic and international legislation regarding the implementation of this type of activity, and, at the next stages, to form consistent and comparable statistical indicators to account for the relationship " links between the environment and the economy. In the absence of regulatory accounting in Ukraine in the conditions of organic production, the formation of internal regulatory accounting regulations is a prerequisite for the effective management of such production. The formed system of cost accounting objects, considering the specifics of technological processes of operators of organic production, will allow organizing a separate accounting of costs for the production of organic products, inorganic products, and products of the transition period. A nomenclature of cost accounting items in terms of production of organic production is proposed, the use of which will make it possible to distinguish in accounting the expenses allowed by legislation in terms of production of organic production from expenses for which there are certain restrictions. The features of the functions of primary documents reflecting the costs of organic production are determined and ways to improve the documentation of production processes are proposed. This will improve the information support for product quality control and will allow adapting the accounting support for managing the production costs of organic products to the requirements of the formation of integrated information on environmental and economic accounting.

Keywords: organic production; expenses; accounting; ecological and economic accounting; information; management

\section{INTRODUCTION}

Accounting for income and expenses, especially at the macro level, is far from accurate. It contains a lot of approximations, assumptions and unaccounted for factors. We practically do not take into account in the price of manufactured products the costs and benefits that arise as a result of the impact of the activities of economic entities on the ecoagri-food system, on the life of society as a whole.

Eigenraam and Obst (2020) call this an "external effect". The authors interpret the external effect as positive or negative consequences of the subject's activities that affect others, without being reflected in the price of goods or services. In terms of costs, these are 
those that will be incurred for the restoration of soils, restoration of damaged ecological systems, the costs of end users of substandard products for the maintenance and restoration of health, and so on.

The rapid development of organic production in Ukraine and the world is a response to the desire and growing opportunities of the population to consume healthy food and public awareness of the real threat and harm of industrial agriculture due to negative environmental, social and economic consequences.

Organic agriculture itself is one of the key factors in solving global environmental and social problems and in achieving the goals of sustainable development. Consequently, a growing number of people are interested in obtaining information about the state of development of organic production, its real costs and the cost of organic products and so on.

\section{LITERATURE REVIEW}

Hemmill-Herren, Baker and Daniels (2021) note that behind all the food we eat is hidden a huge number of unaccounted for negative consequences: shallowing of rivers; extraction of nutrients from the soil; discharge of pollutants into the air and water; labour exploitation; carbon dioxide emissions and so on. When we shed light on these interactions, it becomes clear that a hamburger worth 99 cents costs us all much more than the dollar that the consumer hands over to the cashier.

That is, scientists point out that society consuming low-quality and cheap food does not take into account the significant costs it incurs or will bear in the future. After all, that "cheap" hamburger is extremely expensive for society. And these unaccounted, "invisible" costs are not borne by the manufacturer, but by the global community.

Domestic and international practice provides cost accounting only in the "visible range” by analogy with the tip of the iceberg. Using the current methodology, we cannot, for example, really compare the costs and benefits of organic and inorganic products, because accounting provides limited information. Schematically, this can be depicted as follows (Figure 1).

The same, even more so, can be said about statistics as an accounting system that provides information at the macro level. All this makes it impossible to effectively manage the cost of production and consumption of food and leads to the emergence and deepening of global problems. 
Attempts to take into account the costs of interaction between economic activity and the eco-agri-food system are constantly made in world practice. Thus, in 1993, under the auspices of the Commission of the European Communities, the International Monetary Fund, the Organization for Economic Cooperation and Development, the United Nations, and the World Bank, "System of National Accounts” (1993) was adopted, introducing integrated environmental and economic accounting.

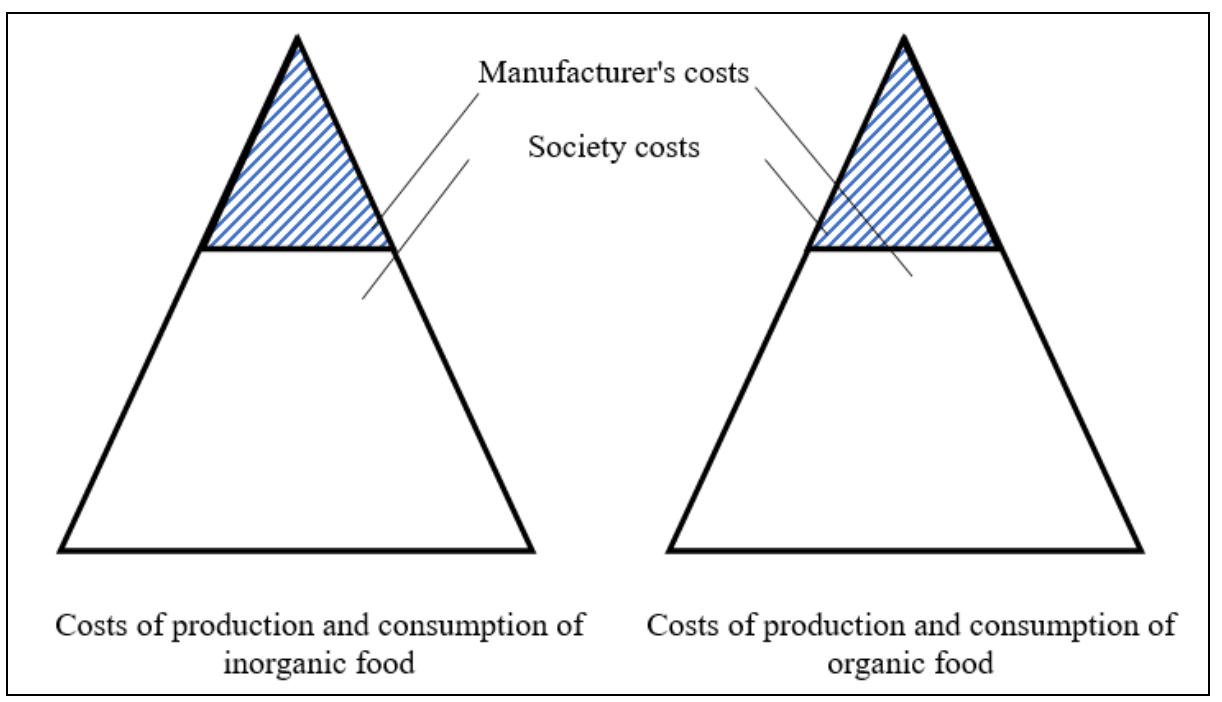

Figure 1: Distribution of food costs in terms of organic and inorganic production Source: created by the authors

In 2012, the United Nations Statistics Commission adopted the "Central Framework of the Natural and Economic Accounting System” as an international statistical standard (2012). The objective of this standard was to develop consistent and comparable statistics to develop a holistic system for taking into account the relationship between the environment and the economy. These documents are statistical tools designed to provide information at the macro level for research and policy making.

The accumulated world experience in the formation of integrated information on environmental, economic and social processes should be used in domestic practice to develop a national system of integrated environmental and economic accounting. At the same time, under the formation of indicators at the macro level, it is necessary to adapt the system of primary monitoring and consolidated accounting indicators.

The works of Ukrainian researchers, in particular Kaletnik and Lutkovska (2021), are devoted to the study of the problems of ecologically oriented activity of the agrarian sector of the economy. The authors propose various forms of public and private partnership to address pressing issues of environmental and economic security. One such way is state support for 
INDEPENDENT JOURNAL OF MANAGEMENT \& PRODUCTION (IJM\&P)

http://www.ijmp.jor.br

v. 12, n. 6, Special Edition ISE, S\&P - November 2021

ISSN: 2236-269X

DOI: 10.14807/ijmp.v12i6.1776

organic production.

Theoretical and methodological foundations of ecological and economic preconditions for the development of organic agriculture were studied by Shkuratov, Chudovska and Vdovychenko (2015). The influence of globalization processes on the development of the market of organic products in Ukraine and the export potential of the Ukrainian organic market is studied in the works of Mazur and Kovalchuk (2018), Honcharuk and Tomashuk (2017) and Kuznetsova et al. (2020).

However, with regard to the accounting of economic activity in the conditions of organic production, it should be noted the lack of scientific developments of theoretical and practical nature. Some issues of organization and methods of accounting are studied in the works of Tsal-Tsalko (2018), Moroz (2019), Nushna et al. (2019) and Semenyshena et al. (2020, 2021) and were considered by the authors of this publication (Ishchenko, 2019; Podolianchuk, 2018).

The purpose of this article is to study the current state of organization and methods of accounting for organic production costs in terms of environmental and economic accounting in Ukraine and provide recommendations for adapting accounting support for organic production costs management to the requirements of integrated environmental and economic accounting.

\subsection{Research methodology}

The methodological basis of the research is general scientific and specific methods.

Among the general scientific methods should be mentioned the system method. Systematic research makes it possible to fully cover and track the process of organic production; its qualitative characteristics; changes that occur at each stage of development. The system approach makes it possible to analyze organic production from the standpoint of integrity and interconnection of the main elements, their impact on the environment.

The general dialectical approach is crucial for the methodology of research of organic production. Its application allows us to recognize the contradictions between industrial agriculture and organic production, between traditional economic interests and the environmental imperative.

The combination of dialectical and systemic approaches to the knowledge of phenomena and processes has made it possible to outline trends in the development of 
INDEPENDENT JOURNAL OF MANAGEMENT \& PRODUCTION (IJM\&P)

http://www.ijmp.jor.br

v. 12, n. 6, Special Edition ISE, S\&P - November 2021

ISSN: 2236-269X

DOI: 10.14807/ijmp.v12i6.1776

ecological and economic accounting in the context of organic production.

Methods of induction and deduction, monographic method, method of theoretical generalization and comparison and method of concretization were used to reveal and deepen the essence and identification of objects of accounting of organic production.

The methodological principles of accounting were studied using a questionnaire, a graphical method, and a method of causation. Methods of extrapolation and analogy served to determine the directions of development of domestic accounting of organic production, taking into account international experience.

Induction and deduction methods were used to determine the general trends in the development of accounting for the costs of organic production. Methods of theoretical generalization and comparison are used to reveal the nature and content of the costs of organic production and organic products as economic categories and objects of accounting. Economic and statistical methods were used to analyze the state of organic production, and the method of observation - to study the state of accounting support for cost management of organic agricultural production.

The sources of the study were the data of the official websites of the International Federation of Organic Agricultural Movement (IFOAM), the Federation of Organic Movement of Ukraine; legislative acts of Ukraine regulating the requirements for organic production, circulation and labeling of organic products; information of the United Nations Statistical Commission, economic literature on the research.

\section{RESULTS}

According to the International Federation of the Organic Agricultural Movement (IFOAM), organic agriculture is a holistic production system that preserves soils, ecosystems, food and nutrition. Such a system is designed to create conditions that support environmentally, socially and economically feasible agricultural production (International Federation of Organic Agriculture Movement. 2021).

In recent years, there has been a positive global trend for all key indicators of organic production (Table 1). 
INDEPENDENT JOURNAL OF MANAGEMENT \& PRODUCTION (IJM\&P)

http://www.ijmp.jor.br

v. 12, n. 6, Special Edition ISE, S\&P - November 2021

ISSN: 2236-269X

DOI: 10.14807/ijmp.v12i6.1776

Table 1: Organic production: key indicators and leading countries

\begin{tabular}{|c|c|c|c|c|}
\hline \multirow[t]{2}{*}{ Indicators } & \multicolumn{2}{|l|}{ World } & \multicolumn{2}{|c|}{ Leading countries } \\
\hline & 2018 & 2019 & 2018 & 2019 \\
\hline $\begin{array}{l}\text { Number of countries } \\
\text { with organic } \\
\text { production } \\
\end{array}$ & 186 & 187 & $\mathrm{x}$ & $\mathrm{x}$ \\
\hline $\begin{array}{l}\text { Area of agricultural } \\
\text { lands with organic } \\
\text { status, million hectares }\end{array}$ & 71,5 & 72,3 & $\begin{array}{l}\text { Africa: } 2 \text { million hectares (Tunisia } \\
\text { 306,467 hectares) } \\
\text { Asia: } 6.5 \text { million hectares (China } 3.1 \\
\text { million hectares) } \\
\text { Europe: } 15.6 \text { million hectares (Spain } 2.2 \\
\text { million hectares) } \\
\text { Latin America: } 8 \text { million hectares } \\
\text { (Argentina } 3.6 \text { million hectares) } \\
\text { North America: } 3.34 \text { million hectares } \\
\text { (US } 2 \text { million hectares) } \\
\text { Oceania: } 36.0 \text { million hectares (Australia } \\
35.7 \text { million hectares) }\end{array}$ & $\begin{array}{l}\text { Australia (35.7 million } \\
\text { hectares) } \\
\text { Argentina ( } 3.7 \text { million } \\
\text { hectares) } \\
\text { Spain (2.4 million } \\
\text { hectares) }\end{array}$ \\
\hline $\begin{array}{l}\text { Share of organic lands } \\
\text { in the total area of } \\
\text { agricultural lands, } \%\end{array}$ & 1,5 & 1,5 & $\begin{array}{l}\text { Africa: 3\% (Sao Tome and Principe } \\
\text { 22.5\%) } \\
\text { Asia: 0.4\% (Timor-Leste 16.8\%) } \\
\text { Europe: 3.1\% (Liechtenstein 38.5\%) } \\
\text { Latin America: } 1.1 \% \text { (Uruguay 14.9\%) } \\
\text { North America: } 0.8 \% \text { (Bermuda } 2 \% \text { ) }\end{array}$ & $\begin{array}{l}\text { Liechtenstein (41.0\%) } \\
\text { Austria (26.1\%) } \\
\text { Sao Tome and } \\
\text { Principe }(24.9 \%)\end{array}$ \\
\hline $\begin{array}{l}\text { Number of operators } \\
\text { of organic production }\end{array}$ & $\begin{array}{c}2.8 \\
\text { millio } \\
\mathrm{n}\end{array}$ & $\begin{array}{c}3.1 \\
\text { millio } \\
\mathrm{n}\end{array}$ & $\begin{array}{l}\text { Africa: } 806000 \text { (Uganda } 210 \text { 352) } \\
\text { Asia: } 1.3 \text { million (India } 1 \text { million) } \\
\text { Europe: } 418610 \text { (Turkey } 79563 \text { ) } \\
\text { Latin America: } 227609 \text { (Peru 103554) } \\
\text { North America: 23,957 (United States } \\
\text { 18,166) } \\
\text { Oceania: 20,859 (Papua New Guinea } \\
\text { 12,742) }\end{array}$ & $\begin{array}{l}\text { India (1366226) } \\
\text { Uganda (210353) } \\
\text { Ethiopia (203602) }\end{array}$ \\
\hline $\begin{array}{c}\text { Organic market, billion } \\
\text { euros }\end{array}$ & 96.7 & 106.4 & $\begin{array}{l}\text { USA (40.6) } \\
\text { Germany (10.9) } \\
\text { France (9.1) }\end{array}$ & $\begin{array}{l}\text { USA (44.7) } \\
\text { Germany (12.0) } \\
\text { France }(11.3)\end{array}$ \\
\hline $\begin{array}{l}\text { Consumption per } \\
\text { capita, euros }\end{array}$ & 12.8 & 14.0 & $\begin{array}{l}\text { Denmark (312) } \\
\text { Switzerland (312) } \\
\text { Sweden (231) }\end{array}$ & $\begin{array}{l}\text { Denmark (344) } \\
\text { Switzerland (338) } \\
\text { Luxembourg (265) } \\
\end{array}$ \\
\hline
\end{tabular}

Source: IFOAM Consolidated Annual Report, 2019, 2020.

The area of agricultural land with organic status increased from 11 million hectares in 1999 to 72.3 million hectares in 2019. 200,000 operators of organic production were registered worldwide in 1999. Their number was already more than three million in 2019. The organic market grew from $€ 15.1$ billion in 1999 to $€ 106.4$ billion in 2019 (IFOAM Consolidated Annual Report, 2020).

According to IFOAM, Europe has the largest share of countries where organic farming is cultivated (Table 2). Ukraine is also among them. 
INDEPENDENT JOURNAL OF MANAGEMENT \& PRODUCTION (IJM\&P)

http://www.ijmp.jor.br

v. 12, n. 6, Special Edition ISE, S\&P - November 2021

ISSN: 2236-269X

DOI: 10.14807/ijmp.v12i6.1776

Table 2: Number and share of countries (by regions) that conducted organic production, 2019

\begin{tabular}{|l|c|c|c|}
\hline \multicolumn{1}{|c|}{ Region } & $\begin{array}{c}\text { Number of countries with } \\
\text { organic farming }\end{array}$ & $\begin{array}{c}\text { Number of countries } \\
\text { in the region }\end{array}$ & $\begin{array}{c}\text { Share of countries producing } \\
\text { organic products, \% }\end{array}$ \\
\hline Africa & 47 & 61 & 77 \\
\hline Asia & 42 & 51 & 92 \\
\hline Europe & 48 & 51 & 69 \\
\hline $\begin{array}{l}\text { Latin America and the } \\
\text { Caribbean }\end{array}$ & 33 & 48 & 75 \\
\hline North America & 3 & 4 & 54 \\
\hline Oceania & 14 & 24 & 78 \\
\hline World & 187 & 239 & 94 \\
\hline
\end{tabular}

Source: The World of Organic Agriculture Statistics and Emerging Trends, 2020.

As of the end of 2019, 16.5 million hectares of agricultural land (about 3.3\% of the total area) were used for organic production in Europe, which is almost 6\% higher than in 2018 (Figure 2), there were more than 430 thousand operators of organic production (Figure $3)$.

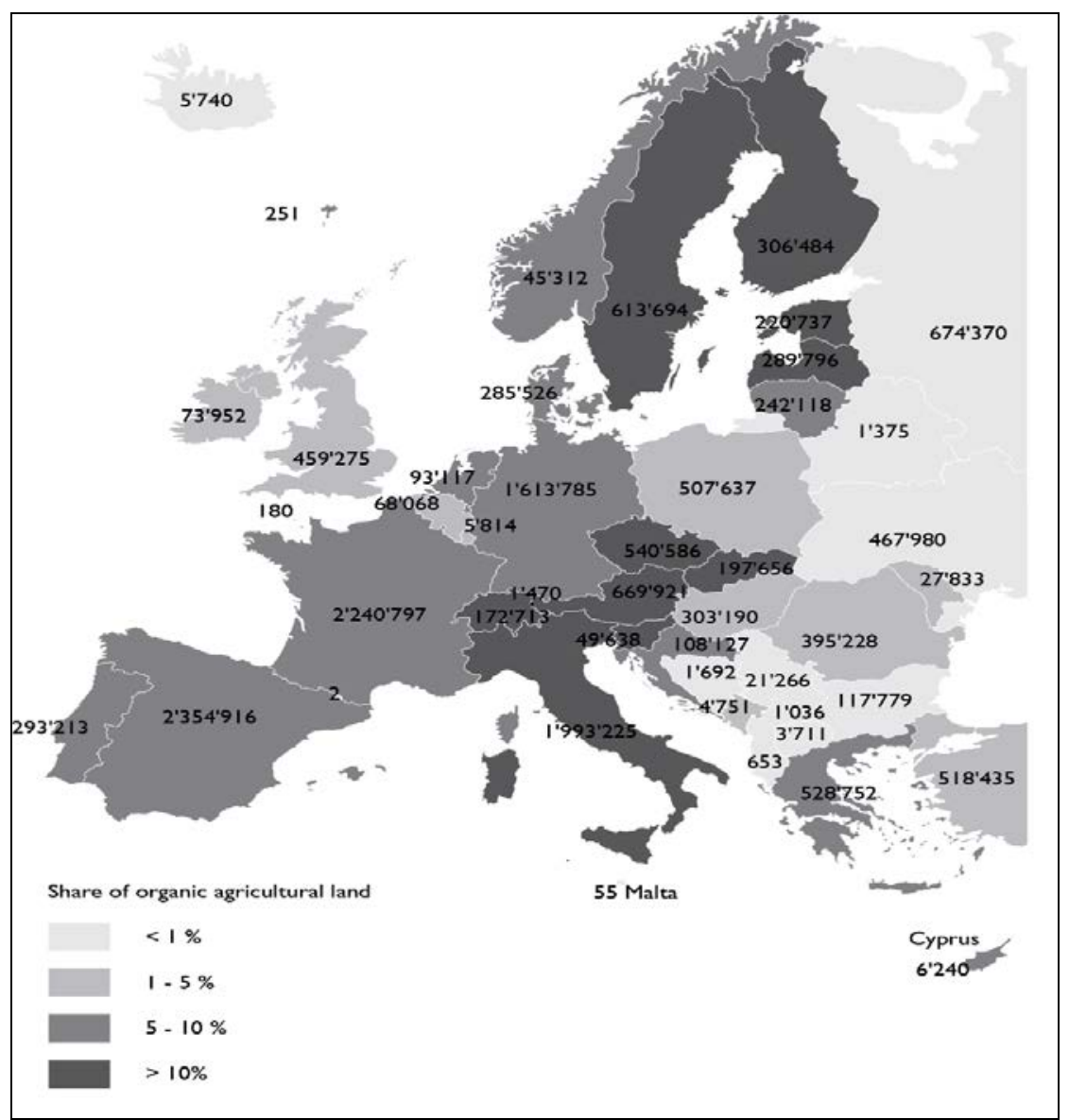

Figure 2: Areas of organic agricultural land in European countries Source: Organic World. Presentations “World of Organic Agriculture 2021”. Part 3: Organic Agriculture in the Regions, 2021.

The largest areas under European production in Europe are in Spain (2.35 million hectares), France (2.24 million hectares), and Italy (1.99 million hectares). The top 3 European countries in terms of the share of organic land are Liechtenstein (41.0\%), Austria 
INDEPENDENT JOURNAL OF MANAGEMENT \& PRODUCTION (IJM\&P)

http://www.ijmp.jor.br

v. 12, n. 6, Special Edition ISE, S\&P - November 2021

ISSN: 2236-269X

DOI: 10.14807/ijmp.v12i6.1776

(26.1\%) and Estonia (22.3\%). Sales of organic products by European countries in 2019 amounted to 45 billion euros, which is $8 \%$ more than last year. The leaders in retail sales of organic products among European countries are Germany (12.0 billion euros), France (11.3 billion euros) and Italy (3.6 billion euros).

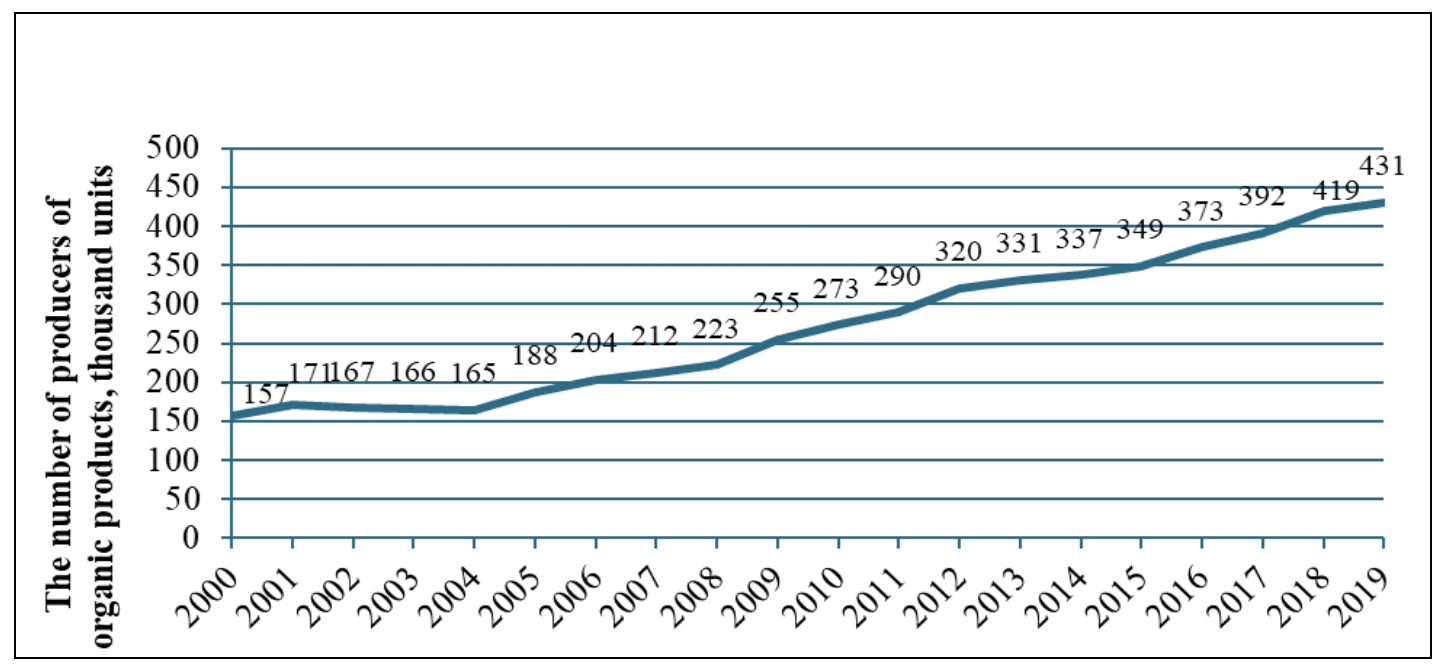

Figure 3: Dynamics of the number of producers of organic products in Europe Source: Organic World. Presentations "World of Organic Agriculture 2021".

Part 3: Organic Agriculture in the Regions, 2021

And although Ukraine is not one of the leading countries in terms of area or production of organic products, in 2019 it took second place among European countries in terms of growth rates of areas involved in organic production (Figure 4). According to the growth of the market of organic products in 2019, Ukraine entered the top 10 European countries and took eighth place (Figure 5).

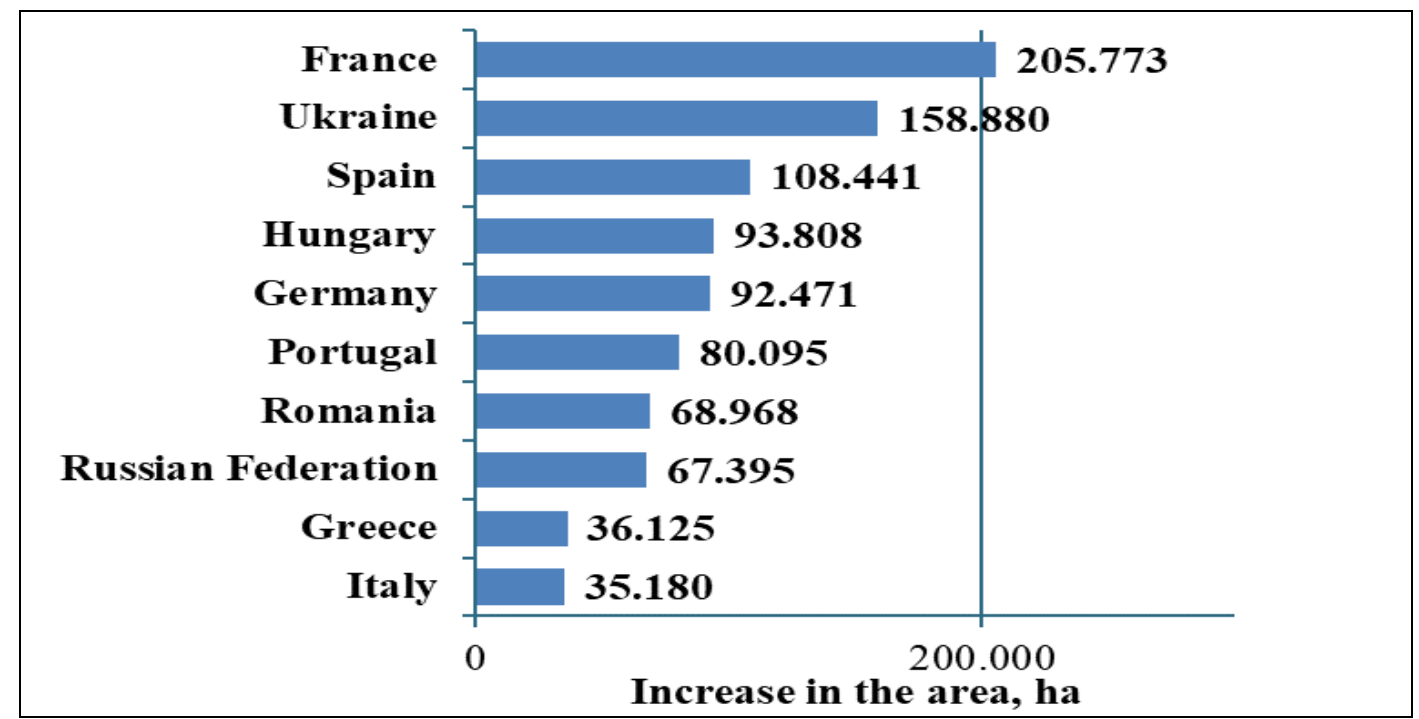

Figure 4: Leading countries with the highest growth of organic agricultural land in 2019, ha Source: Organic World. Presentations "World of Organic Agriculture 2021".

Part 3: Organic Agriculture in the Regions, 2021. 
INDEPENDENT JOURNAL OF MANAGEMENT \& PRODUCTION (IJM\&P)

http://www.ijmp.jor.br

v. 12, n. 6, Special Edition ISE, S\&P - November 2021

ISSN: 2236-269X

DOI: 10.14807/ijmp.v12i6.1776

Ukraine continues to accelerate the development of organic production and according to experts is a promising country for significant expansion of the organic market in Europe.

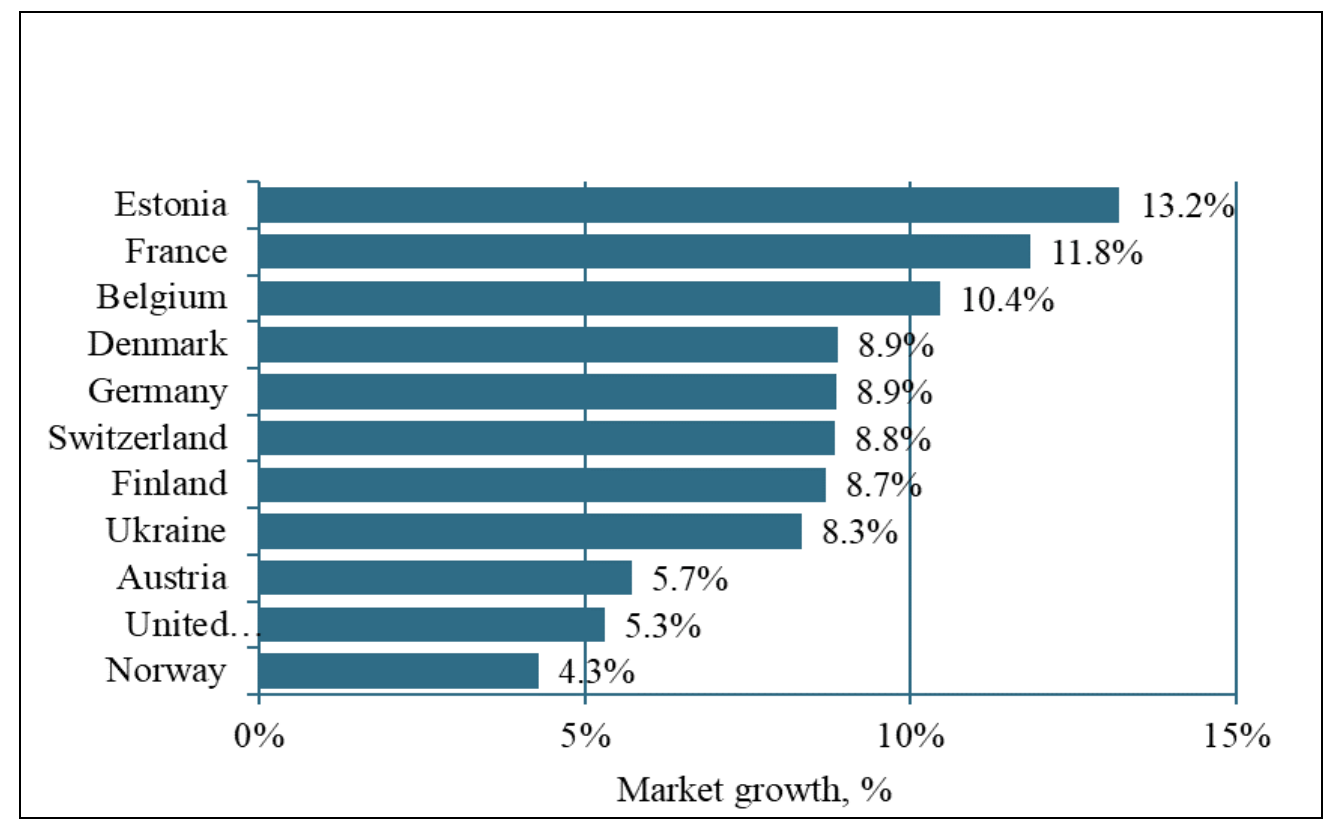

Figure 5: European countries with the highest growth of the organic market in 2018-2019 Source: Organic World. Presentations "World of Organic Agriculture 2021". Part 3: Organic Agriculture in the Regions, 2021

Thus, organic agricultural production in Ukraine is one of the priority areas of development of the agricultural sector of the economy, in accordance with the adopted National Economic Strategy for the period up to 2030. Accordingly, the priority ways to achieve the strategic goals of the state for the development of the agro-industrial sector are:

- implementation of programs to support producers of organic products and implementation of measures aimed at raising awareness of producers about the benefits of organic production;

- development of programs of financial and advisory support for producers of organic products;

- attracting more producers to organic production by improving government regulation in this area;

- ensuring the development of sustainable production, where the task of the government is to encourage sustainable agricultural production, protect the environment and animals, spread the use of organic production methods and biotechnology, "climatefriendly” agriculture and forestry with reduced greenhouse gas emissions and adaptation to climate change, sustainable management of natural resources and 
INDEPENDENT JOURNAL OF MANAGEMENT \& PRODUCTION (IJM\&P)

http://www.ijmp.jor.br

v. 12, n. 6, Special Edition ISE, S\&P - November 2021

ISSN: 2236-269X

DOI: 10.14807/ijmp.v12i6.1776

conservation and enhancement of biodiversity.

The key indicators that characterize the development of organic production in Ukraine are presented in Table 3.

Table 3: Dynamics of organic production development in Ukraine

\begin{tabular}{|l|c|c|c|c|c|c|}
\hline \multicolumn{1}{|c|}{ Indexes } & \multicolumn{5}{c|}{ Years } & $\begin{array}{c}\text { from } 2019 \text { to } \\
2015, \%\end{array}$ \\
\cline { 2 - 7 } & 2015 & 2016 & 2017 & 2018 & 2019 & 294 \\
\hline $\begin{array}{l}\text { Number of operators of organic production, } \\
\text { units }\end{array}$ & 210 & 360 & 375 & 510 & 617 & 114 \\
\hline $\begin{array}{l}\text { Total area of agricultural land with organic } \\
\text { status and transition period, thousand } \\
\text { hectares }\end{array}$ & 410.55 & 411.20 & 420.00 & 429.10 & 467.98 & \\
\hline $\begin{array}{l}\text { Volumes of the domestic consumer market } \\
\text { of organic products, million euro }\end{array}$ & 17.5 & 21.2 & 29.4 & 33.0 & 36.0 & 206 \\
\hline
\end{tabular}

Source: Federation of Organic Movement in Ukraine. Organic in Ukraine, 2021

Organic production as a holistic production system that contributes to environmental and food security, reducing anthropogenic pressure on nature, rational use of natural resources, environmental protection, creating sustainable systems of agricultural production and food processing. This, in turn, minimizes society's costs associated with food production and consumption and increases producer costs.

Thus, the main task of accounting in organic production is the formation of an accounting system that would provide information requests to stakeholders about the costs of organic food producers. After all, at the micro level, in terms of organic production, environmental and economic accounting is an information system that allows you to monitor compliance with domestic and international legislation for this type of activity, and, in the following stages, to form consistent and comparable statistics to take into account relationships between the environment and the economy.

Today in Ukraine there is a lack of information to meet the needs and requests of stakeholders about the state of development of organic production, the cost of production of organic products, its cost, and so on. For effective management of such production at both micro and macro levels, it is essential to provide reliable and complete coverage in management, financial and statistical reporting of information on the costs of production of organic products.

Ukrainian legislation in the field of organic production is currently being formed. The basic normative act that determines the legal, economic and social bases of organic agricultural production in Ukraine is the Law of Ukraine "On production and circulation of organic agricultural products and raw materials” from 03.09.2013, No. 425-VII. This Law 
INDEPENDENT JOURNAL OF MANAGEMENT \& PRODUCTION (IJM\&P)

http://www.ijmp.jor.br

v. 12, n. 6, Special Edition ISE, S\&P - November 2021

ISSN: 2236-269X

DOI: 10.14807/ijmp.v12i6.1776

defines the legal and economic basis for the production and circulation of organic agricultural products and raw materials and aims to ensure the proper functioning of the market of organic products and raw materials, as well as to ensure consumer confidence in products and raw materials labelled as organic (2013).

The law treats the production of organic products (raw materials) as production activities of individuals or legal entities (including cultivation and processing), where such production excludes the use of chemical fertilizers, pesticides, genetically modified organisms (GMOs), preservatives, etc., and all stages of production (cultivation, processing) apply the methods, principles and rules defined by law to obtain natural (environmentally friendly) products, as well as conservation and restoration of natural resources.

The main requirements for organic production are determined by the Law of Ukraine “On Basic Principles and Requirements for Organic Production, Circulation and Labelling of Organic Products” dated July 10, 2018 No. 2496-VIII. This normative act defines organic production as a certified activity related to the production of agricultural products, including all stages of the technological process, namely primary production (including harvesting), preparation, processing, mixing and related procedures, filling, packaging, processing, recovery and other changes in the state of production), which is carried out in compliance with the requirements of legislation in the field of organic production, circulation and labelling of organic products (2018).

The terms "organic crop production”, “organic animal husbandry”, “organic aquaculture” are defined separately in this Law (Table 4).

Table 4: The main categories of organic agricultural production in accordance with the Law of Ukraine "On basic principles and requirements for organic production, circulation and labelling of organic products"

\begin{tabular}{|c|c|}
\hline Terms & Definition of the term \\
\hline $\begin{array}{l}\text { Organic } \\
\text { production }\end{array}$ & $\begin{array}{l}\text { certified activities related to the production of agricultural products, including all stages } \\
\text { of the technological process, namely primary production (including harvesting), preparation, } \\
\text { processing, mixing and related procedures, filling, packaging, processing, recovery and others } \\
\text { changes in the state of production), which is carried out in compliance with the requirements of } \\
\text { the legislation in the field of organic production, circulation and labelling of organic products. }\end{array}$ \\
\hline $\begin{array}{l}\text { Organic crop } \\
\text { production }\end{array}$ & $\begin{array}{l}\text { organic production related to the cultivation of cultivated plants, as well as the } \\
\text { procurement of flora in compliance with the requirements of legislation in the field of organic } \\
\text { production, circulation and labelling of organic products. }\end{array}$ \\
\hline $\begin{array}{l}\text { Organic } \\
\text { animal } \\
\text { husbandry }\end{array}$ & $\begin{array}{l}\text { organic production related to the keeping, breeding (production) of farm animals } \\
\text { (including poultry and insects) and products for the production of products of animal origin. }\end{array}$ \\
\hline $\begin{array}{l}\text { Organic } \\
\text { aquaculture }\end{array}$ & $\begin{array}{l}\text { organic production related to artificial breeding, maintenance and cultivation of } \\
\text { aquaculture facilities in accordance with the requirements of the legislation in the field of } \\
\text { organic production, circulation and labelling of organic products. }\end{array}$ \\
\hline
\end{tabular}

Source: created by the author based on Law of Ukraine, 2018 
The general requirements for organic production determine the need to separate in time or space the production and storage of organic products, including accounting for such products, from the production and storage of inorganic products and products of the transition period (Law of Ukraine. 2018). That is, at the legislative level, operators of organic production are required to organize separate accounting of costs of production of organic, inorganic products and products of the transition period, which must be taken into account when building a system of cost accounting facilities.

The organization of accounting for production costs is a complex process that includes determining the list of items of production costs and their composition; cost accounting objects and calculation objects; structure of sub-accounts and analytical accounts of direct and indirect production costs; the order of reflection of expenses on accounts and ways of inclusion of expenses in the prime cost of each object of calculation; choice of methods of evaluation and accounting of finished products (main, related, secondary), accounting for future expenses; development of methods and techniques for accounting for production costs and forms of internal reporting on costs and output. In addition, in terms of organic production, accounting should be organized by its branches, which include:

- $\quad$ organic crop production (including seed production and nursery);

- organic livestock (including poultry, beekeeping);

- organic mushroom growing (including growing organic yeast);

- organic aquaculture;

- production of organic seaweed;

- $\quad$ production of organic food products (including organic winemaking);

- $\quad$ production of organic feed;

- harvesting of organic objects of flora (Law of Ukraine. 2018).

The objects of cost accounting in agricultural production are traditionally crops (groups of crops), species and groups of animals. However, due to the specifics of technological processes of operators of organic production, the construction of a system of cost accounting facilities for such entities will be somewhat more difficult (Figure 6). 
INDEPENDENT JOURNAL OF MANAGEMENT \& PRODUCTION (IJM\&P)

http://www.ijmp.jor.br

v. 12, n. 6, Special Edition ISE, S\&P - November 2021

ISSN: 2236-269X

DOI: 10.14807/ijmp.v12i6.1776

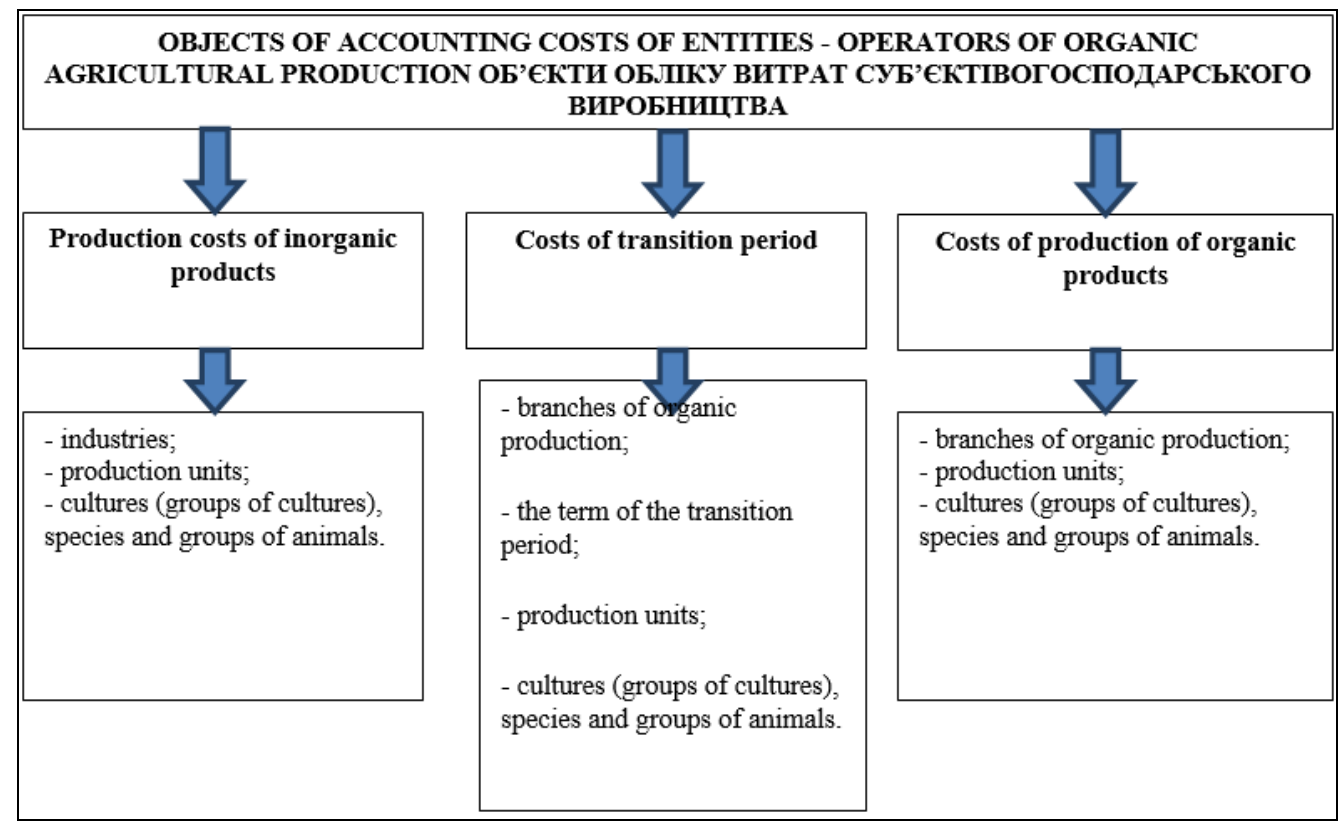

Figure 6: System of objects of accounting of expenses of organic production Source: created by the authors

Accounting is designed to ensure the proper functioning of organic production and consumer confidence in products and raw materials positioned as organic. This is possible provided that all organic production processes are properly documented. The lack of developed standard documents for cost accounting and yield of organic products necessitates the independent formation of a package of primary documents by business entities. This should take into account the standards of organic production, the requirements of current legislation on the production, circulation and labelling of organic products, production technology of products.

When modelling business processes of organic production and the formation of their regulations should take into account the use of cost information. Regarding the accounting support of all levels of management, the primary documents on the costs of organic production should contain information on the following areas of further use:

- operational analysis, internal control and management;

- external control (state control in the field of organic production, circulation and labelling of organic products by operators, control of certification bodies, control of buyers, etc.);

- formation of information for the purposes of financial reporting according to national and international standards;

- formation of information for tax and statistical reporting. 
INDEPENDENT JOURNAL OF MANAGEMENT \& PRODUCTION (IJM\&P)

http://www.ijmp.jor.br

v. 12, n. 6, Special Edition ISE, S\&P - November 2021

ISSN: 2236-269X

DOI: 10.14807/ijmp.v12i6.1776

Therefore, each document must be well thought out and modelled. In a complex with definition of the list of documents it is necessary to form a substantial part of each document which is realized by definition of the necessary information for maintenance of all directions of its use. Under such a comprehensive approach, the primary document will perform control and information functions (Figure 7).

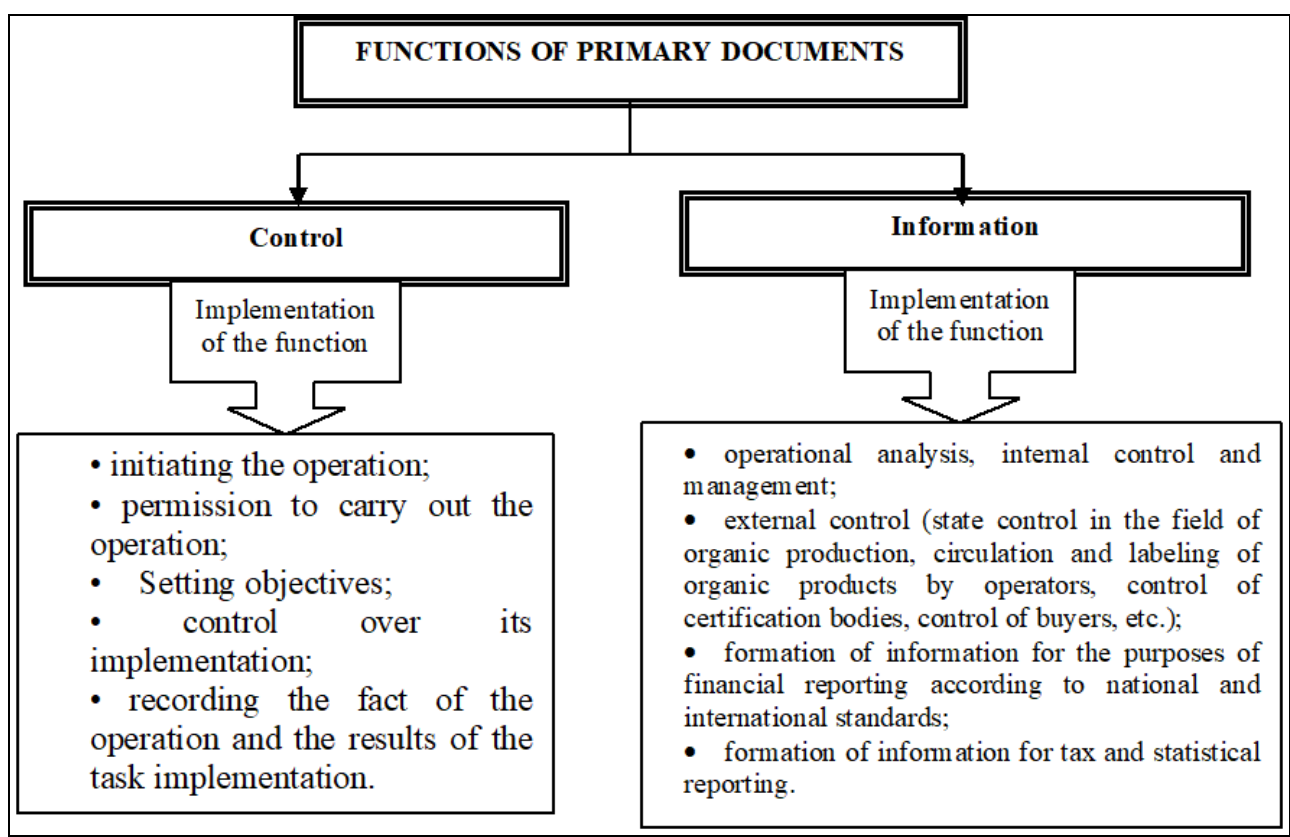

Figure 7: Functions of primary documents in the management of organic production Source: authors' development

Implementation of the internal control function is ensured by initiating the operation, its resolution, setting the task, monitoring its implementation and recording the fact of the operation and the results of the task. The functions of external control in the field of organics in Ukraine are entrusted to certification bodies (during the certification and inspection of production) and the State Service of Ukraine for Food Safety and Consumer Protection (State Food and Consumer Service), which is responsible for state control (supervision) subjects of the market of organic products legislation in the field of organic production, circulation and labelling of organic products.

According to Article 4 of the Law of Ukraine “On Basic Principles and Requirements for Organic Production, Circulation and Labelling of Organic Products”, organic production operators are required to certify their activities annually to confirm compliance with legislation on organic production, circulation and labelling of organic products.

To this end, producers of organic products must cooperate with certification bodies and ensure unimpeded access of organic production inspectors to their facilities and 
INDEPENDENT JOURNAL OF MANAGEMENT \& PRODUCTION (IJM\&P)

http://www.ijmp.jor.br

v. 12, n. 6, Special Edition ISE, S\&P - November 2021

ISSN: 2236-269X

DOI: 10.14807/ijmp.v12i6.1776

sampling, as well as provide, upon request of certification bodies, documents required for certification of organic production, including access to financial documents (Law of Ukraine. 2018). Accordingly, certification bodies have the right to require from the operator documents confirming compliance with the provisions of the legislation on organic production. Such evidence is the primary documents reflecting the cost of production.

The implementation of the information function is ensured by the inclusion in the content of the document of all the necessary information with the selection of its features in the areas of further use. The selection of features of information by areas of use makes it possible to group information for different levels of government, in different sections for the formation of reporting and analytical forms.

In the process of organic production, it is allowed to use only legally defined substances (ingredients, components) and in the maximum allowable quantities. The use of agrochemicals, pesticides, antibiotics for preventive purposes, hormonal drugs, animal growth stimulants, etc. is prohibited (Figures 8 and 9).

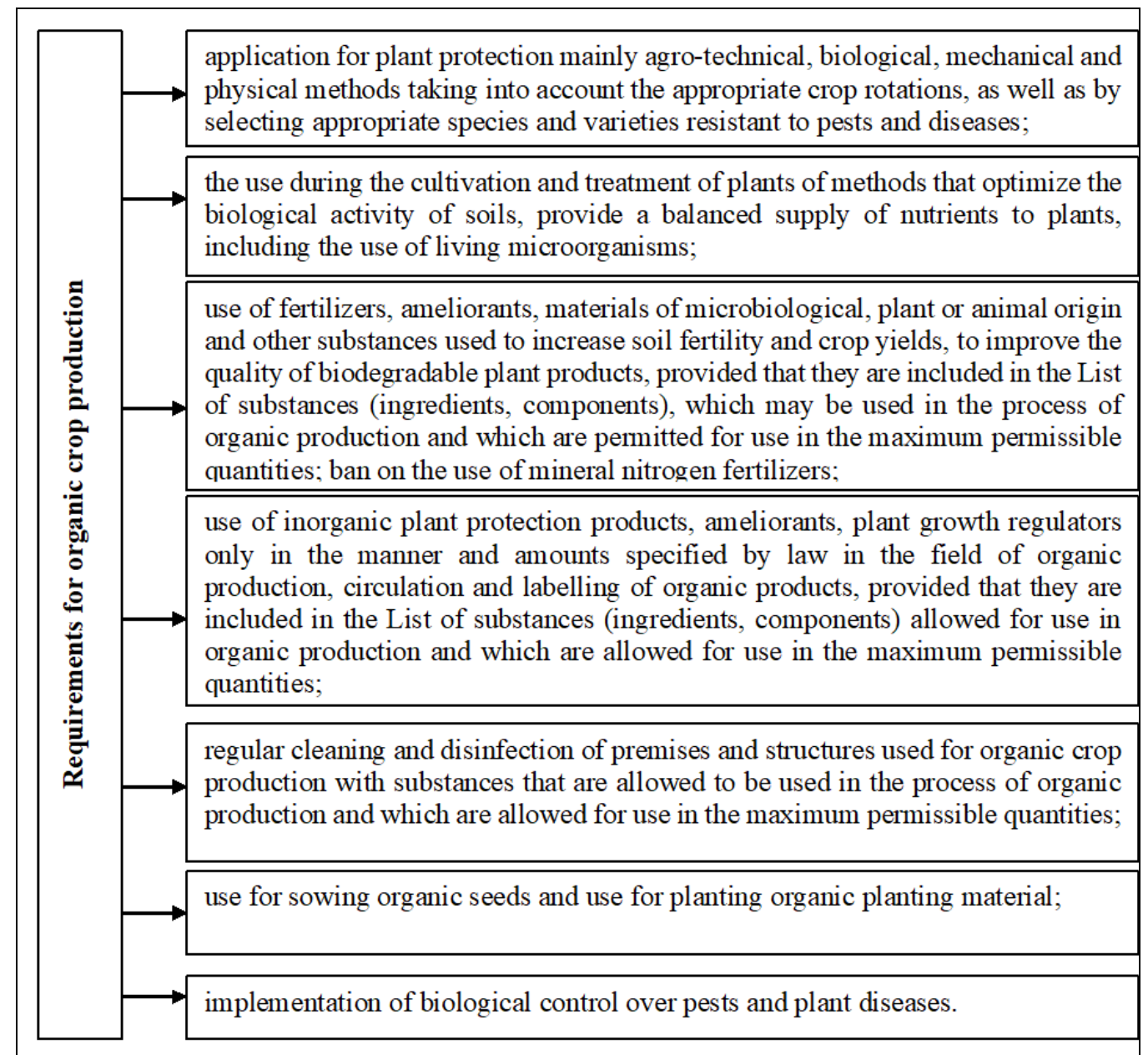

Figure 8: Requirements for the production of organic crop products Source: generated by the author based on Law of Ukraine, 2018 
DOI: 10.14807/ijmp.v12i6.1776

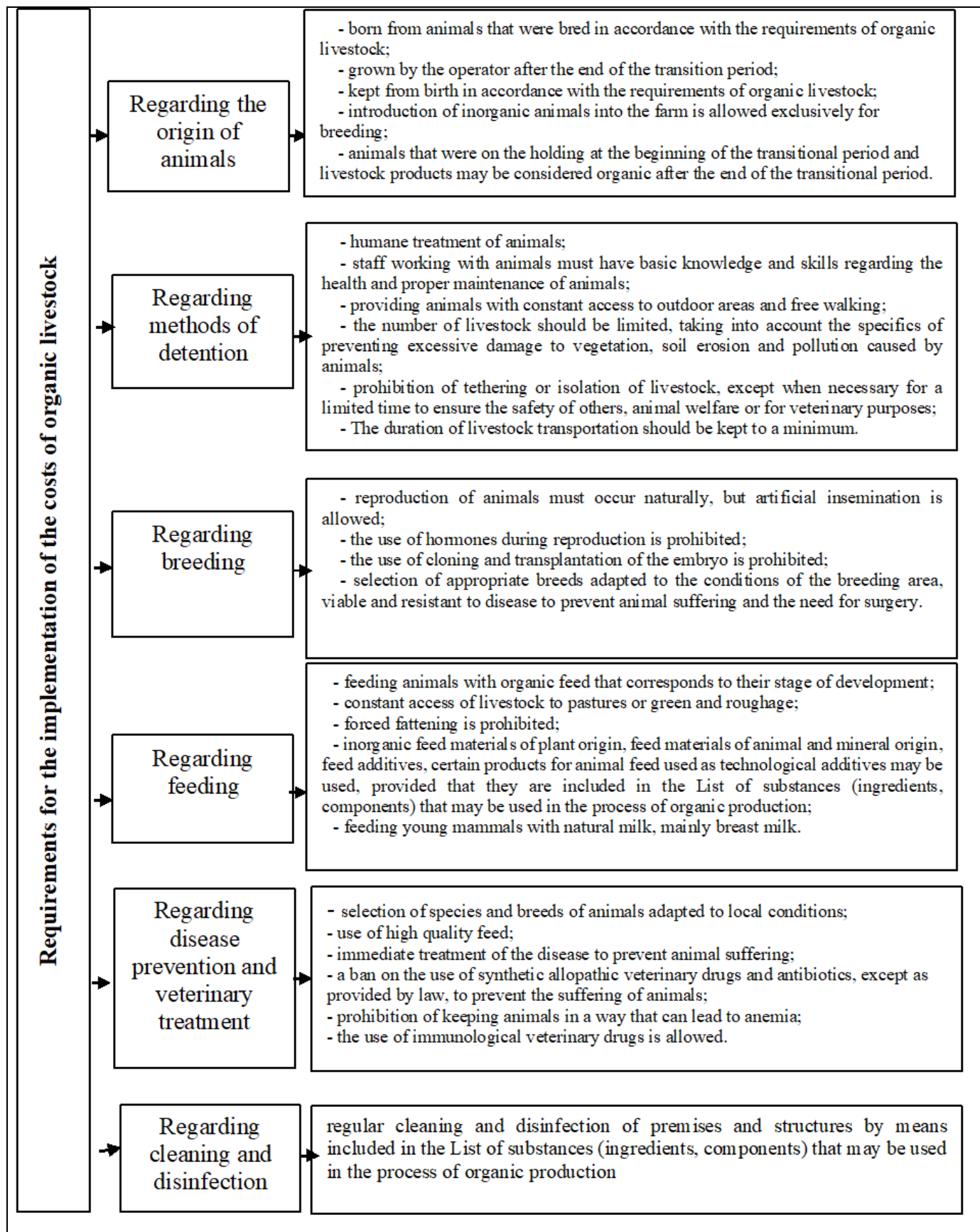

Figure 9: Requirements for the production of organic livestock products Source: generated by the author based on Law of Ukraine. 2018

These requirements and prohibitions necessitate the creation of specialized forms of primary accounting for the costs of seeds, planting material, plant and animal protection products, fertilizers to ensure effective control over the production process of organic products. It should take into account the organizational and technological features and specifics of control during the transition period, in terms of "pure" organic production and in terms of parallel production of organic and inorganic products.

During the transition period and in the conditions of parallel production of organic 
INDEPENDENT JOURNAL OF MANAGEMENT \& PRODUCTION (IJM\&P)

http://www.ijmp.jor.br

v. 12, n. 6, Special Edition ISE, S\&P - November 2021

ISSN: 2236-269X

DOI: 10.14807/ijmp.v12i6.1776

and inorganic products, enterprises need to organize separate storage of stocks for each of the types of production. Incoming accompanying documents should be marked, for example, “organic composition” and “inorganic composition”.

In the case of parallel production, the operator is obliged to provide the certification body with documentary evidence of compliance with the provisions of Article 26 of Law No. 2496-VIII and ensure:

- taking appropriate measures for the permanent separation of organic and inorganic products, the separation of organic and inorganic animals;

- separation of manure and feed;

- proper cleaning of production equipment for technological operations with organic products;

- submission to the certification body of information on the quantity of produced organic products and products of the transition period, inorganic products;

- submission to the certification body of information on harvesting not later than two working days before the beginning of harvesting;

- submission to the certification body of information on any movement or sale of animals, livestock products;

- submission of information to the certification body on the harvest, livestock and livestock products and measures taken to separate organic and inorganic products (Law of Ukraine. 2018).

To provide documentary evidence of these measures to the standard and specialized agricultural forms of primary documents, it is necessary to enter additional details. It is advisable to form additional forms of documents that are necessary to confirm compliance with the law, but are not in the list of already developed forms.

Legislative restrictions on organic production stipulate a particularly detailed organization of accounting for the costs of seeds, planting material, plant and animal protection products, fertilizers to ensure effective control over the production process. This can be achieved by grouping and accounting for costs by costing items.

Accordingly, enterprises-operators of organic production should form an expanded nomenclature of cost items related to the use of these tangible assets (Table 5). 
INDEPENDENT JOURNAL OF MANAGEMENT \& PRODUCTION (IJM\&P)

http://www.ijmp.jor.br

v. 12, n. 6, Special Edition ISE, S\&P - November 2021

ISSN: 2236-269X

DOI: 10.14807/ijmp.v12i6.1776

Table 5: Comparison of the nomenclature of items of accounting for the costs of traditional and organic agricultural production

\begin{tabular}{|c|c|}
\hline \multicolumn{2}{|c|}{ Cost accounting items } \\
\hline $\begin{array}{l}\text { Traditional production (approximate list } \\
\text { according to Methodical recommendations } \\
\text { No. } 132 \text { from } 18.05 .2001 . \text { ) }\end{array}$ & Organic production (suggested by the author) \\
\hline 1 & 2 \\
\hline Salary expenses & Salary expenses \\
\hline Seeds and planting material & $\begin{array}{l}\text { Seeds and planting material: } \\
\text { - purchased organic; } \\
\text { - grown in the transition period; } \\
\text { - grown in organic production; } \\
\text { - others }\end{array}$ \\
\hline Fuel and lubricants & Fuel and lubricants \\
\hline Fertilizers & $\begin{array}{l}\text { Fertilizers: } \\
\text { - fertilizers, ameliorants, microbiological, plant or animal origin; } \\
\text { - other substances used to increase soil fertility and yield of } \\
\text { biodegradable crops; } \\
\text { - fertilizers and substances for soil improvement that can be used } \\
\text { in the process of organic production in the maximum allowable } \\
\text { quantities; } \\
\text { - others. }\end{array}$ \\
\hline Plant and animal protection products & $\begin{array}{l}\text { Plant and animal protection products: } \\
\text { - organic plant and animal protection products; } \\
\text { - inorganic plant and animal protection products, growth } \\
\text { regulators are included in the List of substances (ingredients, } \\
\text { components) that can be used in the process of organic } \\
\text { production; } \\
\text { - others. }\end{array}$ \\
\hline Feed & $\begin{array}{l}\text { Feed: } \\
-\quad \text { made from organic feed materials using mainly biological, } \\
\text { mechanical and physical production methods; } \\
-\quad \text { the content in the feed of not more than one ingredient of } \\
\text { agricultural origin produced during the transition period; } \\
-\quad \text { purchased (meeting the requirements of organic production); } \\
-\quad \text { others. }\end{array}$ \\
\hline Raw materials & $\begin{array}{l}\text { Raw materials: } \\
\text { - raw materials and materials that can be used in the process of } \\
\text { organic production; } \\
\text { - raw materials and materials that can be used in the process of } \\
\text { organic production in the maximum allowable quantities; } \\
\text { - others. }\end{array}$ \\
\hline Works and services & Works and services \\
\hline Repair costs of non-current assets & Repair costs of non-current assets \\
\hline $\begin{array}{l}\text { Other expenses for the maintenance of fixed } \\
\text { assets }\end{array}$ & Other expenses for the maintenance of fixed assets \\
\hline Other expenses & Other expenses \\
\hline Non-productive costs (accounting) & Non-productive costs (accounting) \\
\hline Total production expenditures & Total production expenditures \\
\hline
\end{tabular}

Source: formed by the author based on Law of Ukraine. 2018, Methodical recommendations.2001

The proposed system of itemized accounting will make it possible to differentiate the costs allowed by law to be carried out in organic agricultural production and the costs of which there are certain restrictions. This, in turn, will improve the information support of the control function of organic production management and provide an opportunity to reasonably 
INDEPENDENT JOURNAL OF MANAGEMENT \& PRODUCTION (IJM\&P)

http://www.ijmp.jor.br

v. 12, n. 6, Special Edition ISE, S\&P - November 2021

ISSN: 2236-269X

DOI: 10.14807/ijmp.v12i6.1776

calculate the cost of production.

\section{CONCLUSIONS}

In the absence of normative regulation of accounting in Ukraine in terms of organic production, the formation of internal regulatory accounting regulations is a necessary condition for effective management of such production.

The application of the proposed system of cost accounting facilities in the accounting practice of organic producers, taking into account the specifics of technological processes of organic production operators, will allow to organize separate accounting of costs for organic production, inorganic products and transition products.

The introduction of the developed nomenclature of cost accounting items will make it possible to differentiate in accounting the costs allowed by law in terms of organic production from the costs of which there are certain restrictions. This will improve the information support of product quality control and will allow to adapt the accounting support of cost management of organic products to the requirements of the formation of integrated information of environmental and economic accounting.

We believe that promising areas of further research on this issue is the development of methods for cost accounting and costing of organic agricultural products; methods of accounting and distribution of indirect production costs; reflection of relevant information in financial, management and statistical reporting. Given the strategic prospects for the development of organic agricultural production in Ukraine, as part of the concept of sustainable development, it is necessary to develop a unified system of informatization of society to assess the state of organic production, form a strategy for its development and ensure effective management of these processes.

\section{REFERENCES}

Central basis of the System of natural and economic accounting (2017). Retrieved from https://unstats.un.org/unsd/envaccounting/seeaRev/CF_trans/SEEA_CF_Final_ru.pdf. Access: 2 May, 2021. (in Russian)

Commission of the European Communities, International Monetary Fund, Organization for Economic Cooperation and Development, United Nations, World Bank (1993). System of National Accounts 1993. Retrieved from http://unstats.un.org/unsd/nationalaccount/docs/1993sna.pdf. Access: May 02, 2021.

Eigenraam, M., \& Obst, C. (2020). Applying the TEEBAgriFood Evaluation Framework. DOI: $10.13140 / R G \cdot 2.2 .18280 .70406$. 
INDEPENDENT JOURNAL OF MANAGEMENT \& PRODUCTION (IJM\&P)

http://www.ijmp.jor.br

v. 12, n. 6, Special Edition ISE, S\&P - November 2021

ISSN: 2236-269X

DOI: 10.14807/ijmp.v12i6.1776

European Commission, International Monetary Fund, Organization for Economic Cooperation and Development, United Nations, World Bank (2003). Handbook of National Accounting: Integrated Environmental and Economic Accounting 2003, Studies in Methods. Retrieved from http://unstats.un.org/unsd/envaccounting/seea2003.pdf. Access: May 02, 2021.

Federation of organic movement in Ukraine. Organic in Ukraine, (2021). Retrieved from http://organic.com.ua/organic-v-ukraini/. Access: May 02, 2021.

Gemmill-Herren, Lauren E. Baker, \& Paula A. Daniels (2021). True Cost Accounting for

Food. Balancing the Scale. Retrieved from https:/www.routledge.com/True-Cost-

Accounting-for-Food-Balancing-the-Scale/Gemmill-Herren-Baker-

Daniels/p/book/9780367506858.

Goncharuk, I. V., \& Tomashuk, I. V. (2017). Influence of the ecological and economic factor on the features of the organizational and economic mechanism of using the resource potential of rural areas. Ekonomika. Finansy. Menedzhment: aktualni pytannia nauky i praktyky, 4, 52-62. [in Ukrainian].

Guidelines for planning, accounting and calculating the cost of production (work, services) of agricultural enterprises: order of the Ministry of Agrarian Policy of Ukraine dated 05/18/2001. 132. URL: https://zakon.rada.gov.ua/rada/show/v0132555-01

IFOAM (2020). Consolidated Annual Report 2019. Retrieved from https://www.ifoam.bio/sites/default/files/2020-12/AnnualReport2019.pdf. Access: May 02, 2021. Access: May 19, 2021.

IFOAM (2021). Consolidated Annual Report 2020. Retrieved from https://www.ifoam.bio/sites/default/files/2021-06/Annual\%20Report\%202020.pdf. Access: May 19, 2021.

International Federation of Organic Agriculture Movement (IFOAM). Retrieved from https://www.ifoam.bio/. Access: 17 May, 2021.

Ischenko, Ya. P. (2019). Accounting for the costs and yield of organic agricultural products of crop production. Institute of Accounting, Control and Analysis in the Context of Globalization, 3-4, 26-36. [in Ukrainian].

Ishchenko, Ya. P. (2019). Features of the organization of accounting for the costs of organic agricultural production. Ekonomika. Finansy. Menedzhment: aktualni pytannia nauky i praktyky, 7, 122-132. [in Ukrainian].

Kaletnik, G., \& Lutkovska, S. (2021). Implementation of public-private partnership models in the field of ecological modernization of the environmental safety system. European Journal of Sustainable Development, 10(1), 81-89.

Khorunzhak, N., Brukhanskyi, R., \& Ivanyshyn, V. (2019). Logic-statistical information models in control function of Accounting. Independent Journal of Management \& Production, 10(7), 846-871. DOI: http://dx.doi.org/10.14807/ijmp.v10i7.906.

Mazur V. A., \& Kovalchuk S. Ya. (2018). Spetsyfika rynku orhanichnoi produktsii: natsionalnyi ta yevropeiskyi aspekt [Specificity of organic products market: national and European aspect] Ekonomika. Finansy. Menedzhment: aktualni pytannia nauky i praktyky, 4, 7-18 [in Ukrainian].

National Economic Strategy for the period up to 2030: Resolution of the Cabinet of Ministers of Ukraine dated March 3, 2021 No. 179. Retrieved from 
INDEPENDENT JOURNAL OF MANAGEMENT \& PRODUCTION (IJM\&P)

http://www.ijmp.jor.br

v. 12, n. 6, Special Edition ISE, S\&P - November 2021

ISSN: 2236-269X

DOI: 10.14807/ijmp.v12i6.1776

https://www.kmu.gov.ua/npas/pro-zatverdzhennya-nacionalnoyi-eko-a179. Access: 4 May, 2021.

Nuzhna O., Tluchkevych N., Semenyshena, N., Nahirska K., \& Sadovska I. (2019). Making managerial decisions in the agrarian management through the use of ABC-Analysis tool.

Independent Journal of Management \& Production, 10(7), 798-816. DOI:

http://dx.doi.org/10.14807/ijmp.v10i7.901.

On the basic principles and requirements for organic production, circulation and labeling of organic products: Law of Ukraine dated 10.07.2018 No. 2496-VIII. Retrieved from: https://zakon.rada.gov.ua/laws/show/2496-19. [in Ukrainian].

On the production and turnover of organic agricultural products and raw materials: Law of Ukraine from 03.09.2013r. No. 425-VII. Retrivied from:

https://zakon.rada.gov.ua/laws/show/425-18. Access: June 2021. [in Ukrainian].

Organic World. World of Organic Agriculture 2021 presentations. Part 3: Organic agriculture in the regions. Retrieved from https://www.organic-world.net/yearbook/yearbook2021/presentations.html

Podolyanchuk, A. A. (2018). Accounting in the cost management system. An efficient economy, 7. Retrieved from http://www.economy.nayka.com.ua. Access: May 15, 2021. [in Ukrainian].

Radchenko, O., Semenyshena, N., Sadovska, I., Nahirska, K., \& Pokotylska, N. (2020). Foresight Development Strategy of the Financial Capacity: Comparative Study of the Ukrainian Agricultural Sector. Engineering Economics, 31(2), 178-187. DOI:

https://doi.org/10.5755/j01.ee.31.2.24340.

Research Institute of Organic Agriculture FiBL, IFOAM - Organics International. The World of Organic Agriculture Statistics and Emerging Trends 2020. Edited by Helga Willer, Bernhard Schlatter, Jan Trávníyek, Laura Kemper and Julia Lernoud. Retrieved from https://www.organic-world.net/yearbook/yearbook-2020.html. Access: May 11, 2021.

Semenyshena, N., Khorunzhak N., Lazaryshyna, I., Yurchenko O., \& Ostapenko Y. (2021). Accounting Institute: on the Genesis and Impact of Management Revolutions. Independent Journal of Management \& Production, 12(3), s243-s261.

DOI: https://doi.org/10.14807/ijmp.v12i3.1540.

Shkuratov, A. I., Chudovskaya, V. A., \& Vdovichenko, A. V. (2015). Organic agriculture: ecological and economic imperatives of development: monograph. Kiev: DIA. [in Ukrainian].

Tsal-Tsalko, Yu. S. (2018). Statistical and accounting of organic production. Scientific horizons, 5(68), 70-77. [in Ukrainian].

Zdyrko N., Ishchenko Ya., Melnyk O. (2020). Economic development of fishery and accounting support of cost management for biological conversion in fish farming of Ukraine comparing to the other CEE countries. Economic Annals-XXI, 181(1-2), 137-150. DOI: https://doi.org/10.21003/ea.V181-12. 